\title{
Contribution of Capsule to Virulence and Antibiotic Sensitivity of Klebsiella ozaenae Identified by Phenotypic and Molecular Methods
}

\author{
Aalaa Fahim Abbas ${ }^{1 *}$ (D) , Aamal Ghazi Mahdi Al-Saadi ${ }^{1}$ (D) , Anwar Kadhim Hussein ${ }^{2}$ \\ and Azhar Omran Al-Thaheb²
}

${ }^{1}$ Ecology Department, College of science, University of Al-Qadisiyah, Diwaniyah 58001, Iraq. ${ }^{2}$ Biology Department, College of science, University of Babylon, Hilla 51001, Iraq.

\begin{abstract}
The respiratory colonizer $K$. ozaenae can cause a broad spectrum of infections, and it always misdiagnoses by phenotypic procedures. The role of capsule has not been proved in $K$. ozaenae yet. One hundred (100) clinical specimens were taken from patients suffering different infections. After phenotypic identification by cultural, microscopic, and biochemical tests, the suspected $K$. ozaenae isolates subjected to molecular identification using $16 \mathrm{~S}$ rRNA gene. The non-capsulated $K$. ozaenae isolate was prepared from higher muco-viscous capsulated $K$. ozaenae isolate. Mice were injected intraperitoneally by capsulated and non-capsulated $K$. ozaenae, then bacterial burden in the spleen, liver, and blood was compared and histopathological lesions were detected in liver. Susceptibility of $K$. ozaenae with and without capsule to different antibiotics concentrations was tested at $600 \mathrm{~nm}$ wavelength. Phenotypically, $3(3 \%)$ isolates of $K$. ozaenae were identified, while results of 165 rRNA gene were concordant in $2 / 3(2 \%)$ isolates and discordant in $1 / 3(1 \%)$ isolate. Significant differences were showed between the increased log number of capsulated $K$. ozaenae isolate and decreased log number of non-capsulated $K$. ozaenae isolate that recovered from mice spleen, liver, and blood. Severe pathological lesions were observed in mice liver infected by capsulated $K$. ozaenae compared with non-capsulated $K$. ozaenae isolate. No-significant differences were found between the growth of capsulated and non-capsulated $K$. ozaenae isolate treated with the same antibiotic concentration. 16S rRNA are useful molecular tool to avoid misidentification of $K$. ozaenae. Removal of capsule decreases virulence of $K$. ozaenae, but not affect its sensitivity to antibiotics.
\end{abstract}

Keywords: Klebsiella ozaenae, capsule, virulence, 16S rRNA, antibiotic sensitivity.

*Correspondence: alla.fahim@qu.edu.iq; +9647805685185

(Received: 05 April 2019; accepted: 12 June 2019)

Citation: Aalaa Fahim Abbas, Aamal Ghazi Mahdi Al-Saadi, Anwar Kadhim Hussein and Azhar Omran Al-Thaheb, Contribution of Capsule to Virulence and Antibiotic Sensitivity of Klebsiella ozaenae Identified by Phenotypic and Molecular Methods, J Pure Appl Microbiol., 2019; 13(3): 1753-1761. https://doi.org/10.22207/JPAM.13.3.50

C The Author(s) 2019. Open Access. This article is distributed under the terms of the Creative Commons Attribution 4.0 International License which permits unrestricted use, sharing, distribution, and reproduction in any medium, provided you give appropriate credit to the original author(s) and the source, provide a link to the Creative Commons license, and indicate if changes were made. 


\section{INTRODUCTION}

K. pneumoniae divided into three subspecies with different biochemical reactions, but homologous DNAs: K. pneumoniae subsp. pneumoniae, $K$. pneumoniae subsp. rhinoscleromatis, and $K$. pneumoniae subsp. ozaena ${ }^{1,2}$. K. pneumoniae subsp. ozaenae discrete from $K$. pneumoniae subsp. pneumoniae by a negative reaction to malonate test and voges proskauer $^{3}$. K. ozaenae is known to colonize the nasopharynx and implicate as a causative agent of atrophic rhinitis or ozena ${ }^{4}$. K. ozaenae has been emerging as opportunistic pathogen associated with elderly patients, immunocompromised patients, alcoholics, diabetics and AIDS patients. Furthermore, it has been documented as causative responsible of invasive infections including pituitary abscess, cerebral abscess, splenic abscess, hepatic abscess, bacteremia, meningitis, pneumonia, cholecystitis, urinary tract infection, and soft tissue infections ${ }^{5-8}$.

Klebsiella has a number of factors that involved in its virulence and pathogenicity, including capsule, fimbrial and non fimbrial adhesins, lipopolysaccharide and siderophores ${ }^{9}$. Capsular polysaccharide is the key agent of Klebsiella spp. Its different composition in different clinical isolates leads to differences in the serotypes of these bacteria, and it is directly responsible for the initial stages of pathogenesis. In addition, it is associated with mucosal epithelial cells, and its presence affects the process of building the adhesion proteins necessary for the adhesion and colonization of the intestinal tract of mice ${ }^{10}$. Unlike other intestinal tract bacteria, K. pneumoniae has a thick capsular polysaccharide important in settling, gluing, surviving, and multiplying within the host ${ }^{11}$. It has been observed that capsulated strains were virulent, whereas strains without capsule have minimal virulence or a virulent ${ }^{12}$. The capsule is an extracellular substance composed of hydrophilic polysaccharide arranged in repetitive units that condense in the form of a closely linked layers surrounding the bacterial cell, they immediately react with the outside environments providing protection from host immunity by impairing phagocytosis or block killing by bactericidal serum factors $^{13,14}$. In addition, it confers a physical barrier to detrimental antimicrobial agents, restricts the interaction of the cell surface with antimicrobial peptides ${ }^{15,16}$. Capsular polysaccharide in both Gram negative and Gram positive bacteria has been predicted to impede the antibiotic molecules movement which confer bacteria additional intrinsic mechanism to resist antibiotics ${ }^{17}$. The current study was delineated to isolate and identify K. ozaenae from different clinical infections by phenotypic and molecular methods, and detect the role of capsule in virulence of $K$. ozaenae by comparing the bacterial burden of capsulated $K$. ozaenae isolate with non-capsulated isolate in the spleen, liver and blood of a mouse model through recovering these isolates from the mentioned tissues and determining their log number, with detection the histopathological lesions in liver of inoculated mice, in addition evaluating the role of $K$. ozaenae capsule in antibiotic sensitivity by comparing the growth of capsulated $K$. ozaenae isolate with non-capsulated at different antibiotics concentrations.

\section{MATERIALS AND METHODS}

Specimens collection and bacterial identification

A total of 100 different clinical specimens were collected from patients who were admitted to General Al-Qasim hospital in Babylon province in Iraq. The specimens (blood, urine, sputum, stool, wounds swabs, burn swabs, ear swabs, and throat swabs) were plated on MacConkey agar and incubated at $37^{\circ} \mathrm{C}$ for 24 hours. Suspected pink and mucoid colonies were transferred and purified to individual colonies and phenotypically identified by cultural, microscopic, and biochemical tests according to the methods adopted by ${ }^{18}$. Suspected $K$. ozaenae isolates were further subjected to molecular identification using specific primer based on $16 \mathrm{~S}$ rRNA gene for confirmed isolation.

\section{Molecular identification of $K$. ozaenae}

Bacterial RTP ${ }^{\circledR}$ extraction Kit supplemented by (InVitek- Germany) was used to extract the genomic $K$. ozaenae DNA. Oligonucleotide primers was designed using the clone manager software to amplify $16 \mathrm{~S}$ ribosomal RNA gene from the isolated Klebsiella pneumoniae subsp. ozaenae based on the published corresponding sequence of $16 \mathrm{~S} r$ RNA gene of Klebsiella pneumoniae subsp. ozaenae strain ATCC 11296 (NCBI Reference Sequence: NR_119276. 1). The forward primer sequence was: 5' AGGCCTAACACATGCAAGTC 3 ' and the 
reverse primer sequence was: 3'GTAGCTTAAC CTTCGGGAGG5'. PCR reactions were implemented in a total volume of $50 \mu \mathrm{l}$ mixture using Thermo Scientific $^{\text {TM }}$ Phusion High-Fidelity DNA Polymerase (Fisher scientific) containing $25 \mu \mathrm{L}$ of $2 \mathrm{X}$ Phusion Master Mix, $0.5 \mu \mathrm{M}$ for each primer, $100 \mathrm{ng} / 50 \mu \mathrm{L}$ of genomic $K$. ozaenae DNA, and water exempt from nuclease. The parameters of PCR reaction were as follow: $98^{\circ} \mathrm{C}$ for each of the first and second denaturation steps for 30 and 10 seconds, annealing at $54^{\circ} \mathrm{C}$ (30 seconds); the extension step was done for 1 minute at $72^{\circ} \mathrm{C}$, and the last extension step for 5 minutes at $72^{\circ} \mathrm{C}$. Negative control (without DNA) PCRs were utilized to avoid false positive results. The amplified PCR products were electrophoresed using $1 \%$ agarose gels and spotted with ethidium bromide and imaged using a Bio-Rad ChemiDoc MP.

\section{Detection the presence of capsule}

The presence of capsule in $K$. ozaenae isolates was detected using negative staining method $^{19}$. The higher muco-viscous phenotype of $K$. ozaenae was detected using string test ${ }^{18}$.

Preparation of non-capsulated $K$. ozaenae isolate Non-capsulated $K$. ozaenae isolate was prepared from higher muco-viscous $K$. ozaenae isolate by elimination of capsular polysaccharide through rapid agitation method ${ }^{20}$ as following: 2-4 pure higher muco-viscous $K$. ozaenae colonies were inoculated into $10 \mathrm{ml}$ of phosphate buffer saline, gently shaken up by hand then shaken up by vortex for $5 \mathrm{~min}$, washed twice with phosphate buffer saline then centrifuged for 2 minutes at $18000 \mathrm{rpm}$ and suspended with phosphate buffer saline. Thereafter washed twice by phosphate buffer saline, shaken up by vortex, and then centrifuged for 3 minutes at $18000 \mathrm{rpm}$ and suspended with phosphate buffer saline. The suspension then checked for sterility and stored at $4^{\circ} \mathrm{C}$.

\section{Experimental animals}

Swiss mice, Albino Balb/c, Mus musculus, white, aged 8-12 weeks, ranged between 2024 grams. The mice were obtained from the Embryonic Research Institute in Baghdad province and placed in cages inside the animal house, taking into account the cleanliness of drinking water, feed and sterilization from time to time. All procedures were completed in accordance with guide for the care and use of laboratory animals ${ }^{21}$.

\section{Bacterial virulence assay}

Capsulated and non-capsulated $K$. ozaenae isolates were grown and then suspended at $10^{8} \mathrm{CFU} \backslash \mathrm{ml}$ of phosphate buffer saline. Separate two groups of mice (12 mice in each one) were intraperitoneally injected, the first one with capsulated $K$. ozaenae suspension, while the second group with non-capsulated $K$. ozaenae suspension. Three mice from each group were sacrificed at18-24-48-72h interval post-injection, and cardiac blood, liver and spleen tissues were sampled. Viable numbers of capsulated and noncapsulated $K$. ozaenae isolates were enumerated in the samples by colony count method. At $72 \mathrm{~h}$ after inoculation, the liver samples of inoculated mice were processed to detect histopathological changes $^{22-24}$.

\section{Antibiotic growth test}

Different antibiotics (ampicillin, amoxicillin, doxycycline, and cephalexin, amikacin, naldixic acid) with final concentrations of $12.5,25$, $50,75,125,250,500 \mu \mathrm{g} / \mathrm{ml}$ were prepared with final concentration $10^{8} \mathrm{CFU} \backslash \mathrm{ml}$ of capsulated and noncapsulated $K$. ozaenae isolates. After incubation at $37^{\circ} \mathrm{C}$ for $18 \mathrm{~h}$, bacterial growth turbidity was determined by measuring the absorbance at optical density of $600 \mathrm{~nm}$ wavelength ${ }^{25}$.

\section{Statistical analysis}

The mean of replicate samples was specified and levels of statistical significant differences between experimental groups were calculated by independent $t$ test using SPSS version 20. The results with a P value of $\leq 0.05$ were treated to be significant.

\section{RESULTS}

\section{Isolation percentage of $K$. ozaenae}

The results of cultural, microscopic, and biochemical tests revealed that out of total of 100 different clinical specimens, $3(3 \%)$ isolates were positive for $K$. ozaenae (table 1 ). Confirmative molecular identification of $K$. ozaenae using $16 \mathrm{~S}$ rRNA gene as a molecular marker showed that the blood isolate and the stool isolate were positive for $16 \mathrm{Sr}$ RNA gene with (2\%) of isolation, where the urine isolate was negative for 16Sr RNA gene (Fig. 1).

\section{Detection of $K$. ozaenae capsule}

Negative staining method showed that all three isolates of $K$. ozaenae had capsule. The $K$. 


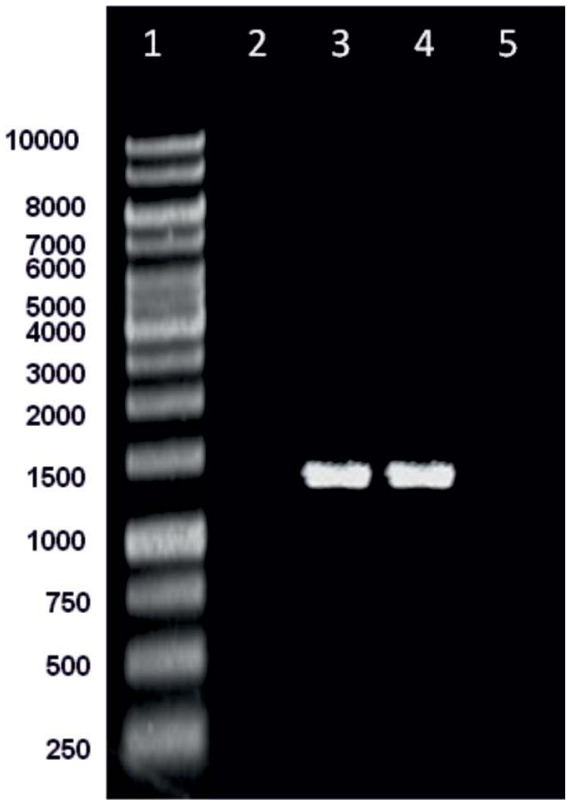

Fig. 1. PCR analysis of the $16 \mathrm{Sr}$ RNA gene of Klebsiella pneumoniae subsp. ozaenae isolated in the current study. Lanes are: (1) Molecular marker, (2) negative urine isolate for $16 \mathrm{Sr}$ RNA gene $(3,4)$ : positive blood and stool $K$. ozaenae isolates for $16 \mathrm{Sr}$ RNA gene (5) negative control. Product expected size is $1413 \mathrm{bp}$.

ozaenae isolate that isolated from blood specimen characterized by production of colonies with string-like growth more than $5 \mathrm{~mm}$. This higher muco-viscous $K$. ozaenae isolate was used in preparation the non-capsulated $K$. ozaenae isolate as described in materials.

\section{Effect of capsule in virulence of $K$. ozaenae}

This study conducted to evaluate the role of capsule in virulence of $K$. ozaenae. Bacterial burden in spleen, liver and blood of mice intraperitoneally inoculated with $10^{8} \mathrm{CFU} \backslash$ $\mathrm{ml}$ of capsulated and non-capsulated $K$. ozaenae isolates was detected at18-24-48-72h intervals post-inoculation by determination the log of viable number of bacteria recovered from spleen, liver and blood. The results indicated significant differences between the increased log number of the capsulated $K$. ozaenae isolate and decreased log number of non-capsulated $K$. ozaenae isolate that recovered from mice organs as explained in (Fig. 2, 3, 4). The log number of capsulated $K$. ozaenae isolate recovered from mice spleen, liver and blood raises with time inoculation from 18 to 72 hours, whereas the log number of non- capsulated $K$. ozaenae isolate recovered from mice spleen, Liver and blood shows a little increase at $24 \mathrm{~h}$ then declines obviously at $48 \mathrm{~h}$ and $72 \mathrm{~h}$ post inoculation. Liver sections were prepared from mice at 72 hour after inoculation with capsulated

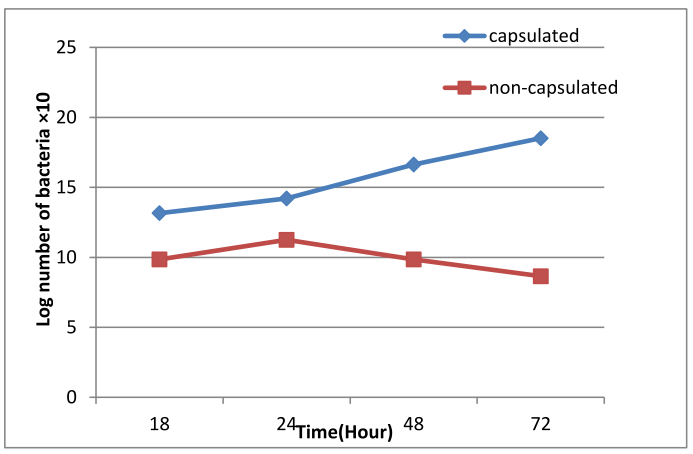

Fig. 2. Viable count of capsulated and non-capsulated $K$. ozaenae recovered from mice spleen. Each dot acts $\log 10$ CFU per gm of spleen (mean) for 3 mice.

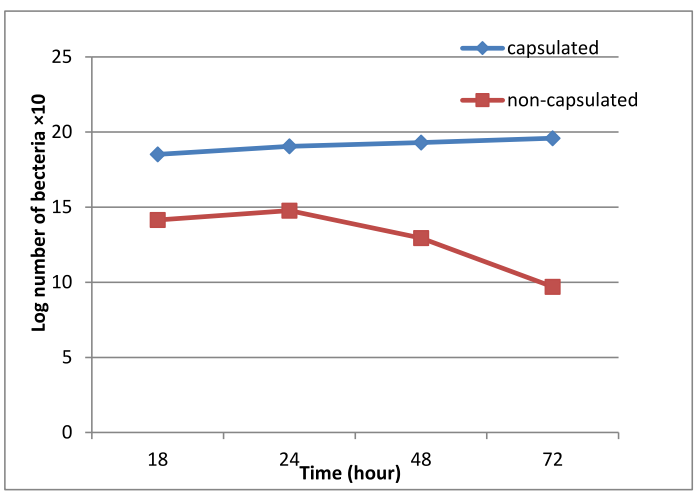

Fig. 3. Viable count of capsulated and non-capsulated $K$. ozaenae recovered from mice liver. Each dot acts $\log 10$ CFU per gm of liver (mean) for 3 mice.

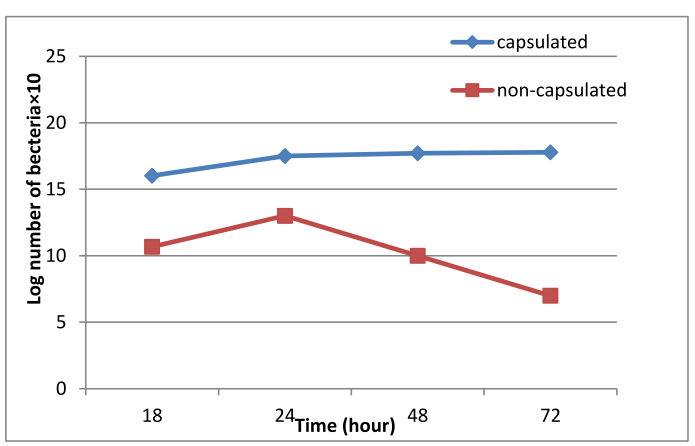

Fig. 4. Viable count of capsulated and non-capsulated $K$. ozaenae recovered from mice blood. Each dot acts $\log 10$ CFU per of blood (mean) for 3 mice. 
and non-capsulated $K$. ozaenae isolates. The histopathological examination of liver sections revealed pathological lesions resulting from infection with capsulated $K$. ozaenae including Kupfer cell hyperplasia, foci of inflammation and migration of polymorphonuclear cell with congestion. The liver sections of mice inoculated with non-capsulated $K$. ozaenae isolate shows minimal lesions represented by mild degeneration (Fig. 5).

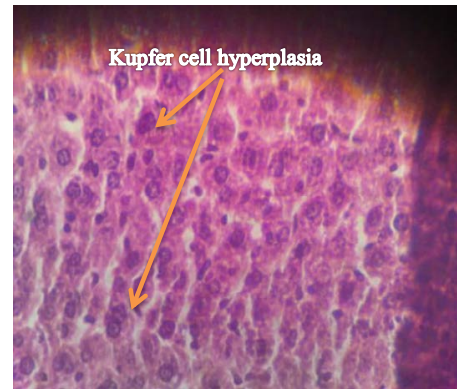

A

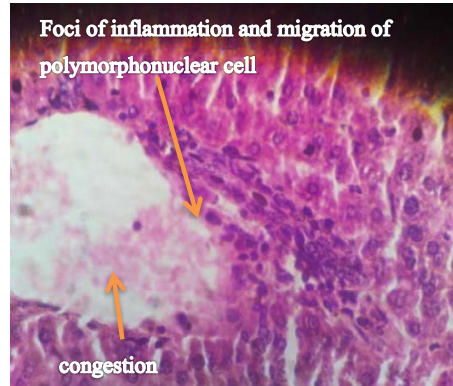

B

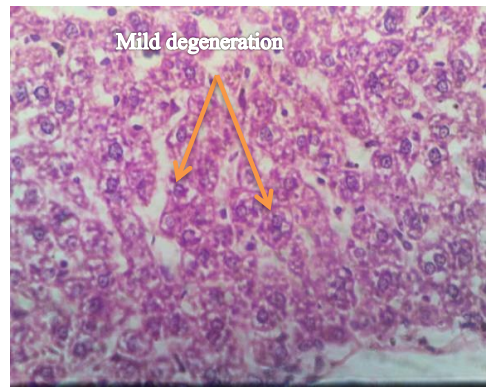

C

Fig. 5. Cross-liver sections from mice injected intraperitonally with (A, B) capsulated $K$. ozaenae isolate shows: A: Kupfer cell hyperplasia, B: acute inflammatory cell infiltration (foci of inflammation and migration of polymorphonuclear cell with congestion. C: with non-capsulated $K$. ozaenae isolate show :mild degeneration (H\&E. 200X).
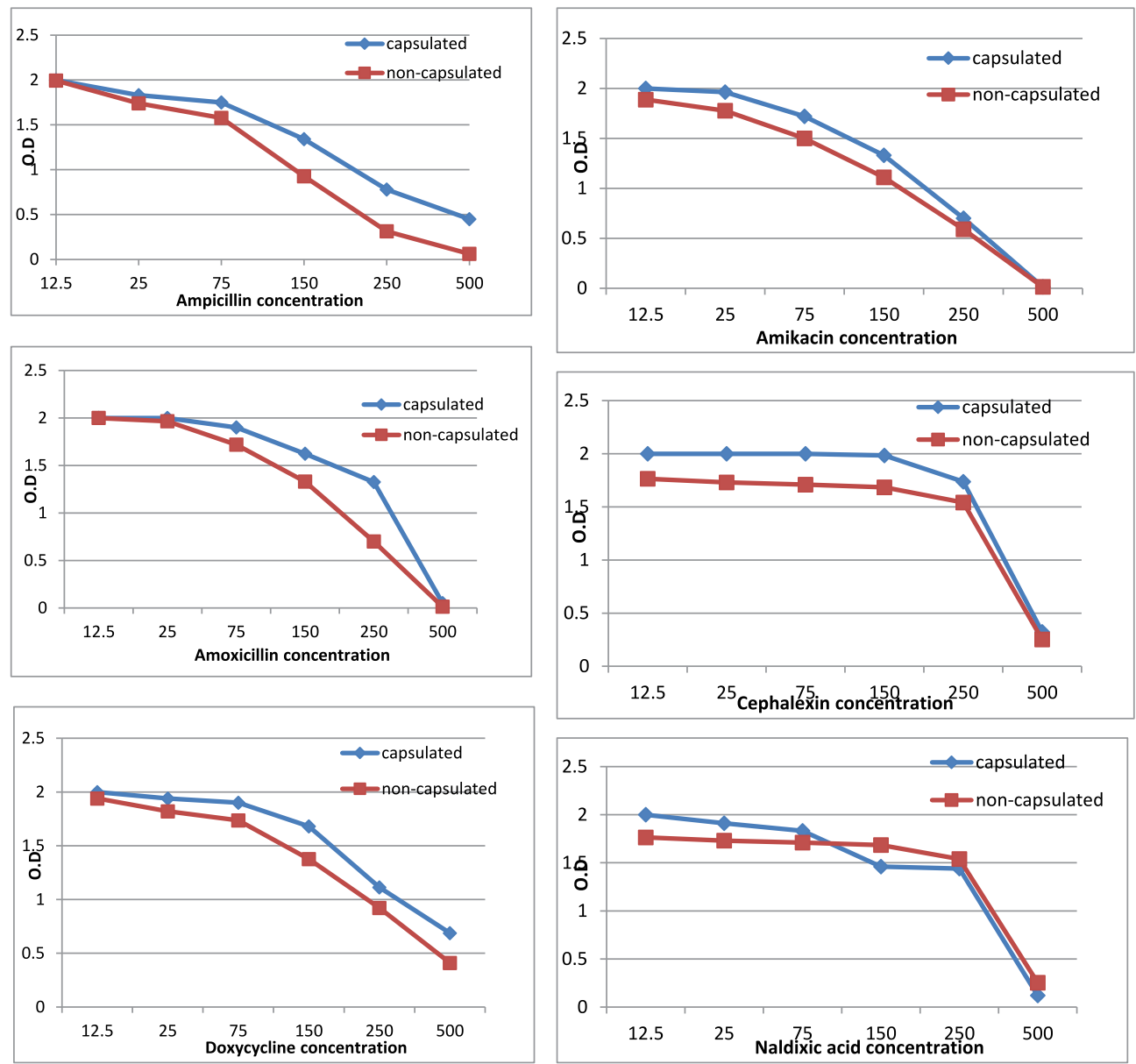

Fig. 6. Changes in growth of capsulated and non-capsulated $K$. ozaenae isolates at different antibiotics concentrations. 
Table 1. Specimens profile and isolation percentage of $K$. ozaenae identified by phenotypic and molecular methods

\begin{tabular}{lccc}
\hline $\begin{array}{l}\text { Types of } \\
\text { specimens }\end{array}$ & $\begin{array}{c}\text { Numberof } \\
\text { specimens }\end{array}$ & $\begin{array}{c}\text { Number of } K \text {. ozaenae } \\
\text { Isolates identified by } \\
\text { phenotypic method (\%) }\end{array}$ & $\begin{array}{c}\text { Number of } K \text {. ozaenae } \\
\text { isolates identified by } \\
\text { molecular method (\%) }\end{array}$ \\
\hline Blood & 10 & $1(1 \%)$ & $1(1 \%)$ \\
Urine & 25 & $1(4 \%)$ & 0 \\
Sputum & 10 & 0 & 0 \\
Stool & 25 & $1(1 \%)$ & $1(1 \%)$ \\
Wounds swabs & 5 & 0 & 0 \\
Burn swabs & 5 & 0 & 0 \\
Ear swabs & 10 & 0 & 0 \\
Throat swab & 10 & 0 & 0 \\
Total & 100 & $3(3 \%)$ & $2(2 \%)$ \\
\hline
\end{tabular}

\section{Effect of capsule in antibiotic sensitivity}

To evaluate the role of capsule in susceptibility of $K$. ozaenae bacteria to antibiotics, the study compared between the growth of capsulated and non-capsulated $K$. ozaenae isolates at different concentrations for ampicillin, amoxicillin, doxycycline, cephalexin, amikacin, and naldixic acid by measuring the absorbance of growth turbidity at $600 \mathrm{~nm}$ wavelength. In general, it was noticed that non-capsulated $K$. ozaenae isolate showed non-significant lower growth compared to the capsulated $K$. ozaenae at the same antibiotic concentration as explained in (Fig. 6). It is noted that the rate of growth gradually decreases with increased antibiotic concentration for $K$. ozaenae isolates with and without capsule.

\section{DISCUSSION}

The respiratory colonizer $K$. ozaenae can cause an extensive infections and even mortality in immunocompromised hosts ${ }^{6}$. The results of phenotypic identification including cultural, microscopic, and biochemical tests revealed that the percentage of $K$. ozaenae among the examined clinical specimens was (3\%). This percentage was agreement with similar study ${ }^{26}$ used phenotypic identification and recorded (2.8\%) isolation percentage of $K$. ozaenae. A misdiagnosis of $K$. ozaenae by biochemical tests has been formerly described $^{27}$, so the phenotypic identification of $K$. ozaenae was not accurate for all isolates because one isolate in our study was a negative for $16 \mathrm{Sr}$ RNA gene. The differences in obtained results by phenotypic and molecular diagnosis might be due to poor sensibility of the former. Molecular identification can promote the diagnostic precision because several molecular targets can offer great sequence symmetry.

K. pneumoniae is characterized by possession of capsular polysaccharide that overlay the bacteria. $K$. ozaenae isolate that isolated from blood specimen, which produced colonies with higher viscus mucus due to the production of large amounts of capsular polysaccharide expressed as higher virulent with higher mucoviscous phenotype. Furthermore this phenotype is characteristic of invasive infections ${ }^{28,29}$.

The significant differences between the increased log number of capsulated $K$. ozaenae isolate and the decreased log number of noncapsulated $K$. ozaenae isolate recovered from liver, spleen, and blood of mice indicate that cellular and humeral bactericidal mechanisms may engage in the clearance of non-capsulated $K$. ozaenae isolate from the host, and the capsule participate in resistance of capsulated $K$. ozaenae to these mechanisms. The capsular polysaccharide is the most important virulence determinant of Klebsiella spp. The mutant Klebsiella strain that lacking or has reduced capsular polysaccharide characterized by reduction in its virulence to the mice which result from increasing the phagocytosis by polymorph nuclear leukocytes or killing of bacteria by serum factors or both ${ }^{13,30}$. The possible mechanisms that explain the role of the capsular polysaccharide in the protection of bacteria from phagocytosis include hydrophilicity of cell surface, the presence of the capsule interferes with the process of opsonization, and capsular polysaccharide mask the lipopolysaccharide 
preventing deposition of complement ${ }^{31}$. It was observed that hydrophobic strains are more readily phagocytosed by polymorph nuclear leukocytes than hydrophilic ones ${ }^{32}$. The tissue infected with $K$. ozaenae manifested large numbers of polymorphnuclear leukocytes, and the capsule interference with these cells prevents them from phagocytosis, thus the numbers of bacteria increased, concerted with sever pathological lesions as shown with presence of inflammation foci in liver sections. The capsular polysaccharide form a soft mucus layer surrounds the solid cell wall and the frequent washing process contributes to its removal. On the other hand, this process cannot remove the lipopolysaccharide that anchor to the outer membrane, and this LPS promote opsonization of $K$. ozaenae when the capsule is detached $^{33}$.

Although the non-capsulated $K$. ozaenae isolate showed lower growth compared to the capsulated $K$. ozaenae when treated with the same antibiotic concentration, differences in the turbidity of the growth of $K$. ozaenae isolates with and without capsule were statically non-significant across all antibiotics concentrations. This indicates that the removal of capsule does not affect the sensitivity of $K$. ozaenae to antibiotics. The intrinsic mechanism that enable the Gram negative bacteria to resist antibiotics is hugely consequent from a cell envelope forming of lipopolysaccharides with little permeability to hydrophobic molecules, multidrug efflux pump system, and slow porins with weakly permeability ${ }^{34-36}$. Susceptibility of $K$. pneumoniae to different classes of antibiotics was not affected in the mutant capsule deficient isolates. Production of penicillinase, Amp C type enzymes, hydrolyzing $\beta$-lactamase, or shelter topoisomerase multination may expedite appearance of Klebsiella pneumoniae resistance to antibiotic ${ }^{37}$.

\section{CONCLUSION}

Molecular identification offer reliable and fast method to overcome misidentification subspecies of Klebsiella pneumoniae. Removal of capsular polysaccharide signi cantly reduces the virulence of $K$. ozaenae, while no compulsory proof that capsule has a role in antibiotic sensitivity; thus the capsule plays an important role in the virulence of $K$. ozaenae, but has no effect in the sensitivity of $K$. ozaenae to antibiotics.

\section{ACKNOWLEDGEMENTS}

None.

\section{CONFLICT OF INTEREST}

conflict of interest.

The authors declares that there is no

\section{AUTHORS CONTRIBUTIONS}

All authors listed have made a substantial, direct and intellectual contribution to the work, and approved it for publication.

\section{FUNDING}

None.

\section{DATA AVAILABILITY}

All datasets generated or analyzed during this study are included in the manuscript.

\section{ETHICS STATMENT}

This article does not contain any studies with human participants or animals performed by any of the authors.

\section{REFERENCES}

1. Drancourt M., Bollet C., Carta A., Rousselier P. Phylogenetic analyses of Klebsiella species delineate Klebsiella and Raoultella gen. nov., with description of Raoultella ornithinolytica comb. nov., Raoultella terrigena comb. nov. and Raoultella planticolacomb. nov. Int. J. Syst. Evol. Microbiol., 2001; 51(Pt3): 925-932. https://doi.org/10.1099/00207713-51-3-925

2. Calfee D.P. Recent advances in the understanding and management of Klebsiella pneumoniae. F1000Res, 2017; 6(1760). https://doi.org/10.12688/f1000research.11532.1

3. Hansen D.S., Aucken H.M., Abiola T., Podschun R. Recommended test panel for differentiation of Klebsiella species on the basis of a trilateral interlaboratory evaluation of 18 biochemical tests. J. Clin. Microbial., 2004; 42(8): 3665-69. https://doi.org/10.1128/JCM.42.8.3665-3669.2004.

4. Endailalu Y.W., Sealy P., Michael M., Al-Halloufi K., Nabhani H. Klebsiella ozaenae sepsis in a young healthy male. Malays J. Pathol., 2012; 34(2): 153-156.

5. Sarma P.S. Klebsiella ozaenae splenic abscess following odontogenic infection in a girl with sickle cell disease. Int. J. Infect. Dis., 2007; 11(1): 86-87. https://doi.org/10.1016/j.ijid.2005.11.003.

6. Ng T.H., How S.H., Kuan Y.C., Adzura N.V., Aziz A.A., Fauzi A.R. A mimicry of melioidosis by Klebsiella ozaenae infection. Malays J. Pathol., 2009; 31(2): 
147-50.

7. Zbar A.P., Ranasinghe W., Kennedy P.J. Subphrenic abscess secondary to Actinomycosis meyeri and Klebsiella ozaenae following laparoscopic cholecystectomy. South Med. J., 2009; 102(7): 725-7. https://doi.org/10.1097/SMJ.0b013e3181abddc5.

8. Kumar S., Alfaadhel T., Albugami M. M. Klebsiella ozaenaebacteremia in a kidney transplant recipient. Case Rep. Transplant, 2013; 2013: 493516. https://doi.org/10.1155/2013/493516.

9. Brisse S., Fevre C., Passet V., Issenhuth-Jeanjean S. Tournebize R., Diancourt L., Grimont P. Virulent clones of Klebsiella pneumoniae: identification and evolutionary scenario based on genomic and phenotypic characterization. PLoS One, 2009; 4(3): e4982. https://doi.org/10.1371/journal.pone.0004982.

10. Schembri M.A., Blom J., Krogfelt K.A., Klemm P. Capsule and fimbria interaction in Klebsiella pneumoniae. Infect. Immun., 2005; 73(8): 4626-33. https://doi.org/10.1128/IAI.73.8.4626-4633.2005.

11. Tomas J.M., Benedi V.J., Ciurana B., Jofre J. Role of capsule and Oantigen in resistance of Klebsiella pneumoniae to serum bactericidal activity. Infect. Immun., 1986; 54(1): 85-89.

12. Cortes G., Borrell N., de Astorza B., Comez C., Sauleda J., Alberti S. Molecular analysis of the contribution of the capsular polysaccharide and the lipopolysaccharide $\mathrm{O}$ side chain to the virulence of Klebsiella pneumoniae in a murine model of pneumonia. Infect. Immun., 2002; 70(5): 2583-90. https://doi.org/10.1128/IAI.70.5.2583-2590.2002.

13. Podschun R. \& Ullmann U. Klebsiella spp. as nosocomial pathogens: epidemiology, taxonomy, typing methods, and pathogenicity factors. Clin. Microbiol. Rev., 1998; 11(4): 589-603. https://doi.org/10.1128/CMR.11.4.589.

14. Doorduijn D.J., Rooijakkers S.H., van Schaik W., Bardoel B.W. Complement resistance mechanisms of Klebsiella pneumoniae. Immunobiology, 2016; 221(10): 1102-9. https://doi.org/10.1016/j.imbio.2016.06.014.

15. Podschun R., Fischer A., Ullman U. Expression of putative virulence factors by clinical isolates of Klebsiella planticola. J. Med. Microbial., 2002; 49(2000): 115-19. https://doi.org/10.1099/0022-1317-49-2-115.

16. Llobet E., Campos M.A., Gimenez P., Moranta D., Bengoechea J.A. Analysis of the networks controlling the antimicrobial-peptide-dependent induction of Klebsiella pneumoniae virulence factors. Infect. Immun., 2011; 79(9): 3718-32. https://doi.org/10.1128/IAI.05226-11.

17. Fowler D., Hu J., Hou P., Wong C. Theeffect of subinhibitory streptomycin on capsular polysaccharide production and streptomycin resistance in Escherichia coli. J. Exp. Microbiol. Immunol., 2009; 13: 47-52.

18. MacFaddin J.F. Biochemical Tests for Identification of Medical Bacteria. 3rd ed. Baltimore: Williams and Wilkins, 2000.

19. Cruckshank R., Duguid J.P., Marmion B.P. and Swain R.H.A. Medical Microbiology. twelve ed. Edinburgh: Churchill Livingstone, 1975.

20. Latef A., Thekra M., Alwazny W.S. Effect of washing and agitation of bacterial suspension in removal capsular polysaccharide for E. coli \& K. pneumonia bacteria. J. Babylon, 2003; 13(3): 517-21.

21. Institute for Laboratory Animal Research. 1996. Guide for the care and use of laboratory animals. Washinton (DC): Natural Academies Press.

22. Allwazny W.S., Nasir A.I., ALganaby N.H. Effect of removal capsular polysaccharides by rapid agitation on Staphylococcus aureus pathogenesis. Med. J. Babylon, 2008; 5(1): 45-51.

23. Chen Jh, Siu L.K., Fung C.P., Lin J.C., Yeh K.M., Chen T.L., Tsai Y.K., Chang F.Y. Contribution of outer membrane protein $\mathrm{K} 36$ to antimicrobial resistance and virulence in Klebsiella pneumoniae. J. Antimicrob. Chemother., 2010; 65(5): 986-90. https://doi.org/10.1093/jac/dkq056.

24. Toledo P.V., Tuon F.F., Bail L., Manente F., Arruda P., Aranha-Junior A.A. Experimental model for treatment of extended spectrum betalactamase producing-Klebsiella pneumoniae. Arq Bras Cir Di, 2014; 27(3): 168-71. https://doi.org/10.1590/S0102-67202014000300002.

25. Domenico P., Schwartz S., Cunha B.A. Reduction of capsular polysaccharide production in Klebsiella pneumoniae by sodium salicylate. Infect. Immun., 1989; 57(12): 3778-82.

26. Al-Kaabi S.J.M. Study of the effect of some antigens of Klebsiella pneumoniae on the immune response. Ph. D. thesis, Collage of Science. Baghdad University, 2006.

27. Arenas N.E., Polanco J.C., Coronado S.M., Durango C.J., Gomez A. Design of a molecular method for subspecies specific identification of Klebsiella pneumoniae by using the $16 \mathrm{~S}$ ribosomal subunit gene. Colomb. Med., 2009; 40(2): 307-15.

28. Russo T.A., Shon A.S., Beanan J.M., Olson R., MacDonald U., Pomakov A.O., Visitacion M.P. Hypervirulent $K$. pneumoniae secretes more and more active iron-acquisition molecules than "classical" $K$. pneumoniae thereby enhancing its virulence. PLoS One, 2011; 6(10): e26734. https://doi.org/10.1371/journal.pone.0026734.

29. Garza-Ramos U., Barrios-Camacho H., Moreno-Dom anguez S., Toribio-Jimenez J., Jardon-Pineda D., Cuevas-Pena J., Sanchez-Perez A., Duran-Bedolla J., Olguin-Rodriguez J., Roman-Roman A. Phenotypic and molecular characterization of Klebsiellaspp. isolates causing community-acquired infections. New Microbes New Infect., 2018; 23: 17-27. https://doi.org/10.1016/j.nmni.2018.02.002.

30. Simoons-Smit A.M., Verweij-van Vught A.M., MacLaren D.M. The role of $\mathrm{K}$ antigens as virulence factors in Klebsiella. J. Med Microbiol., 1986; 21: 133-7. https://doi.org/10.1099/00222615-21-2-133.

31. Paczosaa M.K. \& Mecsas J. Klebsiella pneumoniae: going on the offense with a strong defense. Microbiol. Mol. Bio. Rev., 2016; 80(3): 629-61. https://doi.org/10.1128/MMBR.00078-15.

32. Shutou K., Kanai K., Yoshikoshi K. Virulence attenuation of capsular polysaccharide-deleted mutants of Streptococcus innate in Japanese flounder Paralichthys olivaceus. Fish Pathol., 42(1): 41-48. https://doi.org/10.3147/jsfp.42.41.

33. Cryz S.J., Furer E., Germanier R. Experimental Klebsiella pneumoniaeburn wound sepsis: role of capsular 
polysaccharide. Infect. Immun., 1984; 43(1): 440-41.

34. Geisinger E., \&Isberg R.R. Antibiotic modulation of capsular exopolysaccharide and virulence in Acinetobacter baumannii. PLOS Pathog., 2015; 11(2): e 1004691. https://doi.org/10.1371/journal.ppat.1004691.

35. Wasfi R., Elkhatib W.F., Ashour H.M. Molecular typing and virulence analysis of multidrug resistant Klebsiella pneumoniae clinical isolates recovered from egyptian hospitals. Sci. Rep., 2016; 6(38929). https://doi.org/10.1038/srep38929.
36. Abbas A.F. Antibiotic susceptibility patterns of Burkholderia cepacia isolated from different clinical specimens. J. Babyl. Universit Pure Appl. Sci., 2017; 25(2): 461-72.

37. Hernandez-alles S., Conejo M.D., Pascual A, Tomas J.M., Benedi V.J., Martinez- Martinez L. Relationship between outer membrane alterations and susceptibility to antimicrobial agents in isogenic strains of Klebsiella pneumoniae. J. Antimicrob. Chemother., 2000; 46(2): 273-77. https://doi.org/10.1093/jac/46.2.273. 